\title{
The effect of feeding with low-protein feed mixes on the growth and slaughter value of young male Pharaoh quails
}

\begin{abstract}
Experimental material consisted of one-day Pharaoh quail chicks, which were separated into three experimental groups. The birds of group I received a fodder, the nutritive value of which was consistent with recommended feeding standards for growing quails, whereas for those of group II and III the protein level was lowered in all feed mixes appropriated for the whole rearing period. During the experiment, individual body weight, feed consumption, and bird deaths and their health culling were controlled. At the age of 42 days, 11 males of each group, with a body weight similar to the group mean, were slaughtered. In blood samples collected, the level of amylase was assayed, as well as quail slaughter value was calculated and depot fat and extramuscular fat contents were determined. Meat chemical determinations were made (dry matter, protein and fat contents), as well as physicochemical ( $\mathrm{pH}$, colour, water binding capacity) and sensory ones (cooked meat and bouillon). Basing on the performed examination, it was found that a lowered level of protein in fodder did not affect quail body weight, slaughter yield, or breast part and leg participation in body weight. Carcass fatness decreased and meat water binding capacity improved. The values of majority of other examined meat qualitative traits were similar to those obtained in control group.
\end{abstract}

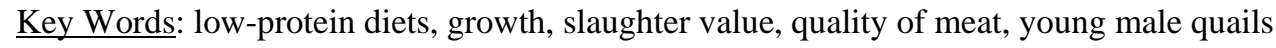

\section{Zusammenfassung}

Titel der Arbeit: Einfluss der Ernährung mit eiweißarmen Futtermischungen auf das Wachstum und die Schlachtleistung junger männlicher Pharaowachteln

Wachteln der Rasse Pharao wurden am ersten Lebenstag drei Versuchsgruppen mit je 120 Tieren zugeordnet. Gruppe 1 als Kontrollgruppe erhielt eine Futtermischung welche den Empfehlungen für wachsende Wachteln entsprach, während für die Gruppe 2 der Eiweißanteil in der Aufzuchtphase mäßig, für die Gruppe 3 stärker reduziert wurde. Erfasst wurden Gewichtsentwicklung, Futterverbrauch, Mortalitätsrate und der Gesundheitszustand der Tiere. Im Alter von 42 Tagen wurden 11 männliche Tiere jeder Versuchsgruppe, die gewichtsmäßig dem Gruppendurchschnitt entsprachen, geschlachtet. Es erfolgte die Bestimmung des Amylasespiegels aus Blutproben sowie der Gewichte und Anteile der einzelnen Teilstücke. Weiterhin konnten am Brustmuskel die chemische Zusammensetzung (Trockenmasse, Eiweiß, Fett), physikochemische - (pH-Wert, Farbe, Wasserbindung) und sensorische Eigenschaften (gekochtes Fleisch und Bouillon) erfasst werden. Es wurde festgestellt, dass die Eiweißreduzierung in den Futtermischungen keinen signifikanten Einfluss auf die Gewichtsentwicklung, die Schlachtleistung und die Brust- und Beinanteile hatte. In den Gruppen 2 und 3 verbesserten sich, abhängig von der Eiweißreduzierung, signifikant Fettgehalt und Wasserbindung. Bei den Qualitätseigenschaften ergaben sich keine Unterschiede zur Kontrollgruppe.

Schlüsselwörter: Proteinniveau im Futter, Wachstum, Schlachtwert, Fleischqualität, Wachtel, Jungtiere

\section{Introduction}

Most consumers expect from manufacturers not only a wholesome but also a cheap food. Application of the lowered level of total protein in poultry diet may be one of means for reducing production costs as well as for smaller fatness of poultry carcasses. Results of research works with the use of lowered protein level in poultry diet do not 
give a clear-cut answer, although in general no worsening of production indicators has been stated (JAMROZ et al., 1981; DASZKIEWICZ et al., 1998; TARASEWICZ et al., 2006), which is a positive phenomenon. In other experiments, a higher body weight of birds fed with low-protein diet was found (PUDYSZAK and MIKULSKI, 1998; ŚWIERCZEWSKA et al., 2000). Positive manifestation of using a lowered protein level in fodder can be a smaller fatness of poultry carcasses stated by some authors (WILKIEWICZ-WAWRO et al., 2003). In the literature, however, there are also reports where smaller gains were found in birds due to feeding with low-protein fodder (OCAK and ERENER, 2005; SHAHIN and EL AZEEM, 2005; DA SILVA et al., 2006; SHAHIN and EL AZEEM, 2006).

The analysis of findings, being exclusive on frequent occasions, collected up to present as well as insufficient number of studies on quail do not allow for a simple answer whether there is a possibility of lowering the level of protein in feed mixes without worsening production indicators and quality of final product in that poultry species. Therefore, there is a need for carrying out further observations that will take into consideration not only a different level of protein but also a composition of feed mix and a production trend, all that against a background of environmental and zoohygienic conditions. The objective of the study was to determine the effect of lower protein level in feed mixes used in quail rearing on production indicators and carcass fatness as well as chemical composition and physicochemical and sensory attributes of the breast muscles of 6-week-old quails.

\section{Material and methods}

Experimental material consisted of Pharaoh quails coming from own clutch. In the experiment, the quails were treated both as production animals and an experimental model for laying hens. The usefulness of quails for model test for hens may be evidenced by the concurrence of results from research carried out on both poultry species. One-day chicks were weighed and separated into three groups. Each group consisted of 120 birds with similar body weight. On day 21 of life, 52 males of each group were selected for further examination. Male selection was made basing on sexual dimorphism in plumage colouration. During the rearing period, quails were kept in cages typical for that species at room temperature and with lighting regime adapted to quail age (RUTKOWSKI, 2000). In control group, quails were fed with standard feed mixes with nutritive value consistent with the NUTRIENT REQUIREMENTS OF POULTRY (1996). In experimental groups II and III, the level of protein in feed mixes appropriated for all rearing stages was lowered. In group II, it amounted to $25 \%$ in the first rearing stage (to 7 days), to $22 \%$ in the second stage (822 days), and to $19 \%$ in the third one (29-43 days), whereas to $22 \%, 20 \%$ and $18 \%$, respectively, in group III. While lowering protein level in feed mixes in relation to that recommended by the NUTRIENT REQUIREMENTS OF POULTRY (1996), their energy value was also reduced in order to maintain the energy-protein ratio at a similar level. The content of calcium and phosphorus as well as that of lysine and methionine in feed mixes fed to all groups in respective stages was similar (Tab. 1).

The quail had a permanent access to fodder (in loose form) and water. Uneaten fodder was weighed once a week. During the experiment, individual body weight was controlled on selected rearing days, i.e. on day 7, 28 and 42 of life (transition from one feed mix to another one with different nutritional value). Also feed consumption in 
respective rearing stages and in the whole rearing period was controlled during observations, as well as bird deaths and their health culling. On day 42 of life, 11 individuals with a body weight approximating the group mean was selected of each group for slaughter. Out of them, blood samples were collected from 10 males of each group for assaying amylase level in their blood serum, which was determined by the kinetic method (CNP-G3). After decapitation, selected internal organs were collected, i.e. liver, gizzard, heart and testicles, for the assessment of their development determined by their proportional participation in body weight. After post-slaughter treatment, carcasses were stored in cooling chamber at about $10^{\circ} \mathrm{C}$ for 24 hours. Thereafter, the amount of depot fat was determined in carcasses, followed by isolation of the breast part with bone and of the leg and determination of extramuscular fat amount in them. Only breast muscles were appropriated for further examination. In these muscles was determined: $\mathrm{pH}$ reaction by measuring it directly in the sample using a $\mathrm{pX}$ processor $\mathrm{PM}-600 \mathrm{pH}$-meter with a combined glass electrode ESAgP-307, colour of fresh muscles using a CIELAB system apparatus as $L^{*}, a^{*}, b^{*}$ (CIE, 1978), and water binding capacity as the content of free water (GRAU and HAMM, 1953). Moreover, the following was also determined in them: basic chemical composition (dry matter, total protein, crude fat, ash), cholesterol content by a colourimeteric method described by KRAUSE et al. (1966), and selected chemical elements (Ca, Na, $\mathrm{K}, \mathrm{Mg}, \mathrm{P}, \mathrm{Fe}, \mathrm{Cu}, \mathrm{Zn}, \mathrm{Se}, \mathrm{Mn}$ ) using an inductively induced plasma optical emission spectrometry (ICP-OES) method. Sensory attractiveness of muscles and bouillon was determined after cooking with water $(1: 3)$ without condiments at $85^{\circ} \mathrm{C}$ until soft. When assessing the sensory attributes of meat and bouillon, a 5-point scale was used, with 1 point being a worse score and 5 points a best one. This assessment was carried out by a 5-person test panel according to the Polish standard PN-ISO 3972. The cooking losses were determined from a difference in meat sample weight before and after cooking.

Table 1

Chemical composition of quail feed mixes in respective rearing stages (\%) (Chemische Zusammensetzung von Futtermischung für Wachteln in verschiedenen Aufzuchtsphasen (\%))

\begin{tabular}{|c|c|c|c|c|c|c|c|c|c|c|}
\hline \multirow[t]{3}{*}{ Item } & \multirow[b]{3}{*}{ Groups } & \multicolumn{9}{|c|}{ Rearing stage } \\
\hline & & \multicolumn{3}{|c|}{ 0-8 days } & \multicolumn{3}{|c|}{ 9-28 days } & \multicolumn{3}{|c|}{ 29-42 days } \\
\hline & & I & II & III & I & II & III & I & II & III \\
\hline Dry matter & & 88.9 & 88.4 & 88.4 & 88.4 & 88.3 & 88.3 & 88.4 & 88.3 & 88.3 \\
\hline Total protein & & 27.9 & 24.1 & 20.3 & 24.1 & 22.4 & 19.3 & 22.1 & 20.2 & 18.2 \\
\hline Metabolic energy (MJ) & & 12.5 & 10.8 & 9.2 & 12.1 & 11.2 & 9.6 & 11.7 & 10.7 & 9.7 \\
\hline Fibre & & 3.9 & 3.8 & 3.6 & 3.9 & 3.7 & 3.4 & 3.5 & 3.4 & 3.3 \\
\hline Calcium & & 1.0 & 1.0 & 1.0 & 0.8 & 0.8 & 0.8 & 0.8 & 0.8 & 0.8 \\
\hline Available phosphorus & & 0.5 & 0.5 & 0.5 & 0.4 & 0.4 & 0.4 & 0.4 & 0.4 & 0.4 \\
\hline Lysine & & 1.6 & 1.5 & 1.5 & 1.3 & 1.2 & 1.2 & 1.0 & 1.0 & 1.0 \\
\hline Methionine + cystine & & 1.1 & 1.1 & 1.1 & 0.9 & 0.9 & 0.9 & 0.7 & 0.7 & 0.7 \\
\hline
\end{tabular}

The obtained results were analysed statistically with one-factor analysis of variance and the Duncan's test using procedures of STATISTICA 6.0 software package. 


\section{Results}

One-day chicks were of a similar body weight, ranging from $7.3 \mathrm{~g}$ in group I to $7.5 \mathrm{~g}$ in group II (Tab. 2). The equalised body weight was also found in quail chicks on day 7 of their life. Significant differences in the body weight of males were found on day 28 of life. Mean body weight in the control group amounted to $120 \mathrm{~g}$ and was higher by 10.7 and $7.7 \mathrm{~g}$ when compared with that of group II and III. Statistically significant differences in the body weight of males were also stated on day 42 of life, being similar in both experimental groups (II and III) but lower by about $7.6 \mathrm{~g}$ when compared to that of control group.

Table 2

Body weight of quails in selected days of live (g) (Körpergewicht bei Wachteln in den verschiedenen Aufzuchtphasen (g))

\begin{tabular}{|c|c|c|c|c|}
\hline \multirow[t]{2}{*}{ Day } & & \multicolumn{3}{|c|}{ Groups } \\
\hline & & I & II & III \\
\hline \multirow{2}{*}{$\begin{array}{l}\text { One-day chicks } \\
\text { (male and female) }\end{array}$} & mean & $7.33 \pm 0.76$ & $7.53 \pm 0.78$ & $7.47 \pm 0.68$ \\
\hline & $\%$ & 100.00 & 102.70 & 101.90 \\
\hline \multirow{2}{*}{$\begin{array}{c}\text { Day } 7 \\
\text { (male and female) }\end{array}$} & mean & $25.56 \pm 3.02$ & $26.27 \pm 3.15$ & $26.92 \pm 2.68$ \\
\hline & $\%$ & 100.00 & 102.77 & 105.32 \\
\hline \multirow{2}{*}{$\begin{array}{c}\text { Day } 28 \\
\text { (male) }\end{array}$} & mean & $120.11 \mathrm{a} \pm 10.64$ & $109.45 b \pm 9.13$ & $112.42 b \pm 10.42$ \\
\hline & $\%$ & 100.00 & 88.60 & 93.60 \\
\hline \multirow{2}{*}{$\begin{array}{l}\text { Day } 42 \\
\text { (male) }\end{array}$} & mean & $167.04 \mathrm{a} \pm 13.22$ & $159.61 \mathrm{~b} \pm 11.13$ & $159.17 b \pm 14.50$ \\
\hline & $\%$ & 100.00 & 95.50 & 95.30 \\
\hline
\end{tabular}

In the first rearing period, the largest amount of fodder was consumed by control group quails (I), in which daily feed consumption per 1 individual amounted to $4.4 \mathrm{~g}$ and was by about $0.5 \mathrm{~g}$ higher on average in relation to that of both experimental groups. In the second feeding stage, feed consumption was similar in all groups $(14.4$ $\mathrm{g}$ on average), whereas in the third rearing period, like in the first one, the highest daily feed consumption was stated in the control group - $30.1 \mathrm{~g}$, with $25.9 \mathrm{~g}$ in experimental groups II and III. However, these differences were not statistically significant. In the whole rearing period, mean feed consumption converted to one quail ranged from $679.0 \mathrm{~g}$ (group III) to $746.7 \mathrm{~g}$ (group I).

Smaller losses due to bird deaths and health culling in quail rearing period were found in both experimental groups, and they were by about $4 \%$ smaller when compared with control group (Tab. 3).

Table 3

Feed consumption by male quails during the rearing period (Futterverbrauch männlicher Wachteln während der Aufzucht)

\begin{tabular}{|c|c|c|c|}
\hline \multirow{2}{*}{ Feed consumption in a given rearing stage } & \multicolumn{3}{|c|}{ Groups } \\
\hline & I & II & III \\
\hline 0-8 days (g/bird/day) & 4.4 & 3.9 & 3.8 \\
\hline 9-28 days (g/bird/day) & 14.5 & 14.4 & 14.3 \\
\hline 29-42 days (g/bird/day) & 30.1 & 25.9 & 25.9 \\
\hline 0-42 days (g/bird) & 746.7 & 681.8 & 679.0 \\
\hline Deaths and health culling to day 42 (\%) & 11.5 & 7.7 & 7.7 \\
\hline
\end{tabular}


The highest level of amylase activity determined in the blood serum of quail males, however not confirmed statistically, was found in group I (177.2 U/L), whereas the lowest one in group II (165.3 U/L) (Fig.).

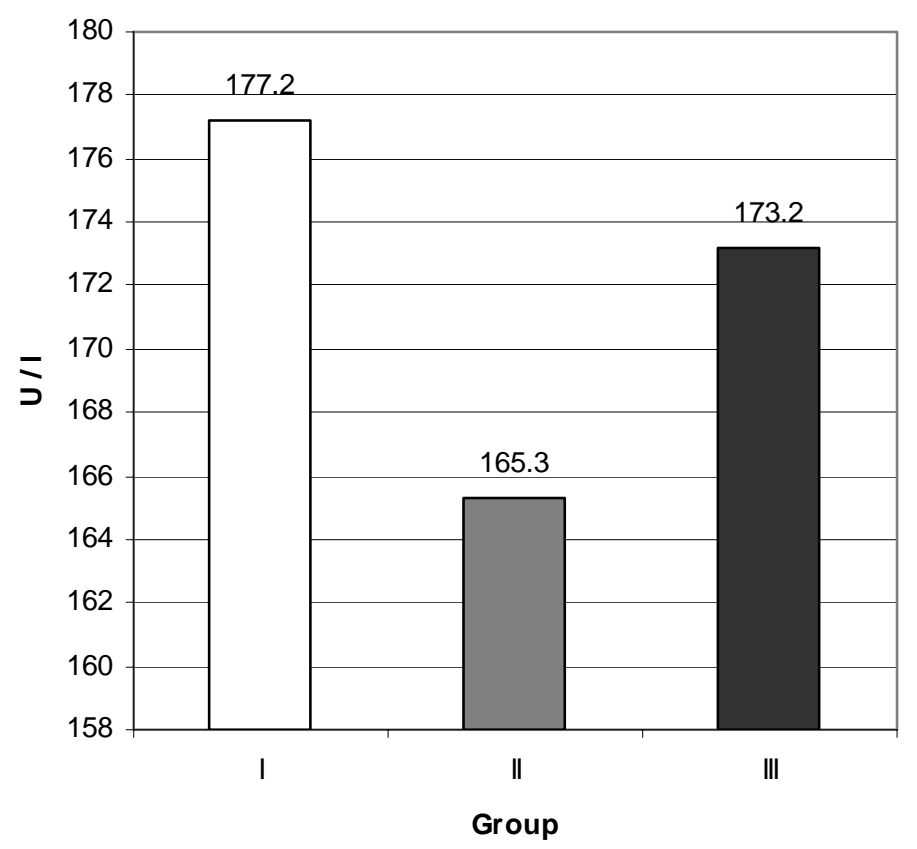

Figure: Activity of blood serum amylase in quail males (Amylaseaktivität im Blutserum von männlichen Pharaowachteln)

Table 4

Slaughter value of male quails (Schlachtleistung bei männlichen Wachteln)

\begin{tabular}{|c|c|c|c|}
\hline \multirow{2}{*}{ Item } & \multicolumn{3}{|c|}{ Groups } \\
\hline & I & II & III \\
\hline Body weight (g) & $165.1 \pm 5.02$ & $159.1 \pm 3.24$ & $159.9 \pm 2.51$ \\
\hline Carcasse (g) & $106,54 \pm 4.10$ & $105,50 \pm 3.05$ & $104,51 \pm 2.72$ \\
\hline Slaughter yield (\%) & $64.53 \pm 3.67$ & $66.31 \pm 2.98$ & $65.36 \pm 2.03$ \\
\hline Breast part with bone (g) & $49.31 \pm 2.54$ & $48.83 \pm 3.01$ & $49.09 \pm 2.25$ \\
\hline Percentage in carcasse & $46.28 \pm 1.87$ & $46.29 \pm 2.07$ & $46.97 \pm 2.11$ \\
\hline Legs part with bone (g) & $31.90 \pm 2.54$ & $29.43 \pm 1.84$ & $28.79 \pm 1.43$ \\
\hline Percentage in carcasse & $29.94 \pm 2.24$ & $27.89 \pm 1.51$ & $27.54 \pm 1.92$ \\
\hline Abdominal fat (percentage in carcasse) & $2.49 \mathrm{a} \pm 2.05$ & $2.26 \mathrm{ab} \pm 2.16$ & $2.02 \mathrm{~b} \pm 2.26$ \\
\hline Fat of muscular (\%) & $3.18 \mathrm{a} \pm 1.52$ & $3.12 \mathrm{a} \pm 1.93$ & $3.00 \mathrm{~b} \pm 1.37$ \\
\hline & Percentage in the body weight & & \\
\hline liver & $2.14 \pm 0.30$ & $2.43 \pm 0.47$ & $2.24 \pm 0.39$ \\
\hline gizzard & $3.00 \pm 0.27$ & $3.12 \pm 0.31$ & $3.09 \pm 0.42$ \\
\hline heart & $0.95 \pm 0.09$ & $0.89 \pm 0.09$ & $0.90 \pm 0.06$ \\
\hline testicles & $2.07 a \pm 0.55$ & $1.41 \mathrm{~b} \pm 0.95$ & $1.33 \mathrm{~b} \pm 0.63$ \\
\hline
\end{tabular}

In order to confirm the proper development and correct functioning of quail organisms, certain internal organs were collected from males and their proportional participation in the body weight was determine. Only small, statistically nonsignificant differences were found in the weight and proportional participation of liver, gizzard and heart in the males on the 42nd day of life. The weight of testicles in the 6th week of life ranged from $2.1 \mathrm{~g}$ (group III) to $3.4 \mathrm{~g}$ (group I), which constituted respectively 1.33 and $2.07 \%$ body weight. These differences in the weight of testicles 
between the control group (I) and experimental ones were statistically significant (Tab. 4).

The weight of male carcasses was similar in all groups and ranged from $104.5 \mathrm{~g}$ (group III) to $106.5 \mathrm{~g}$ (group I), whereas the weight of breast muscles with bone from $48.8 \mathrm{~g}$ (group II) to 49.3 g (group I), which constituted 46.3\% carcass weight (Tab. 4).

In the carried out experiment, the quail fatness was assessed by determining the amount of depot fat and that of fat collected from the surface of whole muscles (cover fat) expressed in the form of proportional participation in the muscle weight. Most depot and cover fat was found in control group (2.5\% and $3.2 \%$, respectively), whereas the least in group III (2.0\% and 3.0\%). These differences between group III and other groups were confirmed statistically (Tab. 4).

It results from the performed chemical analyses that breast muscles of all quail groups contained a similar amount of dry matter (from $27.0 \%$ in group I to $27.5 \%$ in group II) as well as of total protein (from $24.5 \%$ in groups I and II to $24.9 \%$ in group III) (Tab. 5). Least crude fat $(1.76 \%)$ and cholesterol $(0.60 \mathrm{mg} / \mathrm{g})$ was found in control group, however the differences between this group and other groups were statistically nonsignificant. The breast muscles of quails were rich in iron, its amount ranging from 23.3 (group III) to $24.4 \mu \mathrm{g} / \mathrm{g}$ (group I). The evaluated muscles of all quail groups were characterised by a relatively high content of potassium and phosphorus, amounting respectively to 3.8 and $3.9 \mathrm{mg} / \mathrm{g}$ on average, and not differing significantly (Tab. 5). The fed diets did not have any significant effect on the content of any chemical element analysed, not on the ash content in the meat of young quails either.

Table 5

Chemical composition of male quail breast muscles (Chemische Zusammensetzung des Brustmuskels von männlichen Wachteln)

\begin{tabular}{|c|c|c|c|}
\hline \multirow{2}{*}{ Item } & \multicolumn{3}{|c|}{ Groups } \\
\hline & I & II & III \\
\hline Dry matter (\%) & $27.00 \pm 0.58$ & $27.50 \pm 0.51$ & $27.30 \pm 0.49$ \\
\hline Total protein (\%) & $24.50 \pm 0.53$ & $24.50 \pm 0.41$ & $24.9 \pm 0.51$ \\
\hline Fat $(\%)$ & $1.76 \pm 0.56$ & $1.99 \pm 0.48$ & $1.88 \pm 0.44$ \\
\hline Raw ash (\%) & $1.28 \pm 0.12$ & $1.22 \pm 0.10$ & $1.28 \pm 0.08$ \\
\hline Cholesterol (mg/g) & $0.60 \pm 0.06$ & $0.62 \pm 0.07$ & $0.61 \pm 0.06$ \\
\hline \multicolumn{4}{|l|}{ Selected chemical elements } \\
\hline Calcium (mg/g) & $0.11 \pm 0.02$ & $0.11 \pm 0.01$ & $0.11 \pm 0.02$ \\
\hline Sodium (mg/g) & $0.40 \pm 0.06$ & $0.40 \pm 0.02$ & $0.42 \pm 0.07$ \\
\hline Potassium (mg/g) & $3.87 \pm 0.03$ & $3.83 \pm 0.16$ & $3.82 \pm 0.23$ \\
\hline Magnesium (mg/g) & $0.39 \pm 0.03$ & $0.39 \pm 0.02$ & $0.40 \pm 0.02$ \\
\hline Phosphorus (mg/g) & $3.79 \pm 0.51$ & $3.92 \pm 0.22$ & $4.01 \pm 0.33$ \\
\hline Iron ( $\mu \mathrm{g} / \mathrm{g})$ & $24.40 \pm 6.55$ & $23.80 \pm 5.37$ & $23.30 \pm 0.17$ \\
\hline Zinc $(\mu g / g)$ & $8.81 \pm 1.01$ & $8.93 \pm 1.06$ & $9.15 \pm 1.93$ \\
\hline Copper $(\mu \mathrm{g} / \mathrm{g})$ & $1.41 \pm 0.45$ & $1.35 \pm 0.32$ & $1.52 \pm 0.62$ \\
\hline Selenium ( $\mu \mathrm{g} / \mathrm{g})$ & $0.15 \pm 0.06$ & $0.13 \pm 0.08$ & $0.14 \pm 0.03$ \\
\hline Manganese $(\mu \mathrm{g} / \mathrm{g})$ & $0.27 \pm 0.06$ & $0.23 \pm 0.05$ & $0.30 \pm 0.09$ \\
\hline
\end{tabular}

The results of physicochemical and sensory determinations are presented in Table 6 . The reaction $(\mathrm{pH})$ of muscles 24 hours after slaughter ranged from 5.50 to 5.65 and was similar in all examined groups. The results of measurement of such parameters of fresh muscle colour as $\mathrm{L}^{*}, \mathrm{a}^{*}$ and $\mathrm{b}^{*}$ were similar in all quail groups examined and did not differ significantly. The losses of juice during cooking were at a similar level in all examined groups and amounted respectively to $35.8 \%, 35.6 \%$ and $35.8 \%$. No 
statistically significant differences were found between respective groups in that respect.

The statistical analysis of obtained results with respect to the amount of free water as a measure of fresh muscle water binding capacity showed a better water binding capacity of the breast muscles of quail groups III $(0.39 \%)$ and II $(0.45 \%)$, i.e. of groups receiving a smaller amount of protein in feed mixes when compared with control group (0.91\%).

The sensory evaluation of meat from the breast included also such discriminants as flavour, juiciness and tenderness, whereas that for bouillon referred to its colour, aroma and flavour. The flavour of breast meat obtained the highest score in all examined groups, whereas its juiciness from 3.45 (group II) to 3.52 points (group I). Similar score in groups obtained meat tenderness. No significant differences were found in all determined bouillon discriminants either (Tab. 6).

Table 6

Results of physicochemical and sensory analyses of breast muscles (Physikochemische Merkmale und sensorische Analyse des Brustmuskels)

\begin{tabular}{lccc}
\hline \multicolumn{1}{c}{ Item } & \multicolumn{3}{c}{ Groups } \\
& $\mathrm{I}$ & $\mathrm{II}$ & $\mathrm{III}$ \\
\hline $\mathrm{pH}$ & $5.65 \pm 0.19$ & $5.62 \pm 0.14$ & $5.50 \pm 0.20$ \\
$\mathrm{~L}^{*}$ & $35.42 \pm 2.40$ & $35.09 \pm 1.57$ & $33.69 \pm 1.83$ \\
$\mathrm{a}^{*}$ & $11.79 \pm 0.79$ & $12.46 \pm 1.50$ & $11.99 \pm 0.65$ \\
$\mathrm{~b}^{*}$ & $9.29 \pm 0.97$ & $9.79 \pm 1.48$ & $9.35 \pm 0.85$ \\
Thermal drip (\%) & $35.80 \pm 2.35$ & $35.60 \pm 2.18$ & $35.80 \pm 2.06$ \\
Free water (\%) & $0.91 \mathrm{a} \pm 0.38$ & $0.45 \mathrm{~b} \pm 0.29$ & $0.39 \mathrm{~b} \pm 0.37$ \\
& Boiled meat & & \\
Meat flavour (pts) & $5.00 \pm 0.00$ & $5.00 \pm 0.00$ & $5.00 \pm 0.00$ \\
Meat juiciness (pts) & $3.52 \pm 1.05$ & $3.45 \pm 1.04$ & $3.48 \pm 1.07$ \\
Meat tenderness (pts) & $3.53 \pm 0.87$ & $3.48 \pm 1.08$ & $3.50 \pm 1.39$ \\
& Bouillon & & \\
Bouillon colour (pts) & $3.97 \pm 1.08$ & $4.00 \pm 1.04$ & $3.93 \pm 0.97$ \\
Bouillon aroma (pts) & $4.40 \pm 1.10$ & $4.50 \pm 1.10$ & $4.70 \pm 0.96$ \\
Bouillon flavour (pts) & $3.50 \pm 0.95$ & $3.40 \pm 0.77$ & $3.50 \pm 0.92$ \\
\hline
\end{tabular}

$\mathrm{a}, \mathrm{b}$ - values in rows marked with different letters differ significantly $(\mathrm{P}<0.05)$

\section{Discussion}

Earlier studies of HOWES and BEANE (1966) point to a possibility of lowering total protein level in the diet for young quails to $20 \%$ with no negative effect on their body weight gains, providing however for s suitable level of lysine and methionine. In the experiment of VOHRA and ROUDYBUSK (1971), quails fed with a diet containing $20 \%$ total protein weighed about $120 \mathrm{~g}$ in the 6th week of life, whereas those fed with a fodder containing an increased level of protein, to 25\%, weighed about $130 \mathrm{~g}$. The increase of body weight took place with the increase of fodder protein level to $30 \%$, whereas after exceeding over 35\% the body weight increased up to the 2nd week of life only and then a worsening of body weight gain was observed. In the own research, when lowering fodder protein level and maintaining a similar level of lysine and methionine, a lower body weight, by $4.4-4.7 \%$, was observed in the quails of both experimental groups in the final rearing stage when compared to control group. Also OCAK and ERENER (2005) found a negative effect of quail feeding method during the rearing period on their final body weight. However, the cited authors applied in their experiment a feeding reduced by $30 \%$ in relation to recommended standards. 
Also ŁAMBUCKI (2001) in research on hens showed a negative effect of low-protein feed mixes on the final body weight. The reduction of protein level by $10 \%$ brought about a lowering of body weight by $9.6 \%$. Carcasses of broiler chickens fed with low protein diet either low or high fibre ones, had less muscle and fat than carcasses of chickens fed with high protein diet (SHAHIN and EL AZEEM, 2005, 2006).

ŚWIERCZEWSKA et al. (2000) are of the opinion that the quantity of protein, and first of all the energy-protein ratio, determines production results. The cited authors found in their research on chicken broilers that a diverse protein level in feed mixes allowed for obtaining by them a body weight and feed consumption similar to those of control group, when maintaining the same energy-protein ratio. It results from other research works (JAMROZ et al., 1984) that reduction of total protein level in concentrate feed mixes by several per cent induced a lowering, although a slight (1$4 \%$ ) one, of production indicators, including also dissection and biochemical ones, despite supplementing amino acid shortages.

In the own research, the quails of both experimental groups consumed less fodder that those of control group. Similar results were obtained by DA SILVA et al. (2006). In the studies on chicken broilers, the reduction of total protein level in diet diversified feed consumption, i.e. ŁAMBUCKI (2001) showed an increase in feed conversion by about 5\% with reduction of protein level by $10 \%$ in feed mixes for chicken broilers, whereas JAMROZ et al. (1981) and ŚWIERCZEWSKA et al. (2000) did not show any change in feed conversion rate in chicken broilers fed with low-protein fodder. SZCZUREK and PISULEWSKI (1996), when lowering total protein content (to $16.5 \%$ ) in a grower mash enriched in pure amino acids to the level provided for in national standards, did not find a worsening in weight gains and feed conversion, with a simultaneous reduction of discharge of nitrogen compounds in chicken faeces by about 29\%. The lowering of total protein level to $13.5 \%$ worsened production indicators but did not result in a further decrease of nitrogen discharge.

In the present examination, smaller losses due to deaths and health culling, by about $4 \%$, were found in both experimental groups. Also PUDYSZAK and MIKULSKI (1998) inform about no effect of lowered protein level in feed mixes on the losses in quail rearing. GEBHARDT-HENRICH and MARKS (1995), applying restrictive quail feeding, found a considerably higher mortality rate in experimental groups.

The activity of alpha-amylase is a resultant of its formation and excretion processes. In poultry, it depends to a considerable extent on the functioning of pancreas, as salivary alpha-amylase plays a limited part in birds. The obtained results may be evidence of proper maturation of the alimentary tract to digestion of starch from fodder. Usually, a low level of the activity of that enzyme in blood accompanies better feed conversion. The values for the amylase activity in quail blood determined in the experiment were subjected to large variation in individual birds. WERTELECKI and JAMROZ (1997) in a similar experiment carried out on chickens did not find significant differences between groups either.

In the present research, no negative effect was found of low-protein diet on the proportional participation of liver, heart and gizzard in quail body weight, thus the applied feeding did not affect development of these organs, except for a statistically significant one in case of the participation of testicles.

Similar values characterising quail male gonads to those obtained in the present study were reported by MARKS et al. (1990), who at the same time demonstrated that there 
were correlations between testicle weight and depot fat and cholesterol contents in blood. This correlation was confirmed in part by TARASEWICZ (1998). This author recorded the smallest weight of testicles in males of the group that was characterised by the lowest cholesterol content in blood.

The slaughter value, similar in all quail groups examined, showed that fodder protein level did not have any significant effect on that trait, not on the participation of breast part in male carcass weight either. On the other hand, a significant effect was found in case of the participation of legs in carcass weight. Partial confirmation of the obtained results can be found in the paper of OCAK and ERENER (2005), who reported that quail feeding method in the rearing period did not affect the slaughter value, nor the participation of breast muscles in quail carcass.

Basic chemical composition of breast muscles was similar in all examined groups. No significant effect of fodder protein level on meat chemical composition in chickens was reported by ŚWIERCZEWSKA et al. (2000).

In the present research, most depot fat and that on the surface of muscles (cover fat) was found in control group. The reduction of poultry carcass fatness in result of lowering fodder protein level was also observed by ROSEBROUGH and STEELE (1985), MUSCALU et al. (1993), WILKIEWICZ-WAWRO et al. (2003), SHAHIN and EL AZEEM (2006) and KUL et al. (2006).

The acidification of breast muscles after 24 hours from slaughter was similar in all quail groups examined. No effect of feeding on its level was found. The obtained results are in conformity with those received by DASZKIEWICZ et al. (1998).

The measurement of meat colour did not show any effect of the lowered protein level in fodder on colour lightness $\left(\mathrm{L}^{*}\right)$, red colour partcipation $\left(\mathrm{a}^{*}\right)$ and yellow colour participation $\left(\mathrm{b}^{*}\right)$. Similar results were obtained by DASZKIEWICZ et al. (1998), who examined the effect of low-protein diets in quail feeding on the formation of meat colour.

The cooking losses of breast muscles were at a similar level in all quail groups examined, being at the level that is typical for quail meat (GARDZIELEWSKA et al., 2005).

The statistical analysis of the results obtained when determining the amount of free water (as a measure of water binding capacity in muscles) showed a significantly better water binding capacity in the breast muscles of males from both experimental groups, i.e. the groups receiving lower protein amounts. JAMROZ et al. (1984) found a substantial trend for increasing meat water binding capacity when lowering the amount of protein in fodder.

Basing on the performed examination, it was found that a lowered level of protein in fodder did not affect quail body weight, slaughter yield, or breast part and leg participation in body weight. Carcass fatness decreased and meat water binding capacity improved. The values of majority of other examined meat qualitative traits were similar to those obtained in control group.

\section{References}

COMMISSION INTERNATIONALE DE L'ECLAIRAGE (CIE). Colorimetry:

Official Recommendations on uniform color spaces, color difference equations, psychometric color term. Supplement, 2 to CIE Publication nr 15, colorimetry, Paris, France: Bureau Central de la CIE, (1978) 
DA SILVA, E.L.; DA SILVA, J.H.V.; JORDÃO FILHO, J.; RIBEIRO, M.L.G.; COSTA, F.G.P.; RODRIGUES, P.B.:

Reduction of the dietary protein levels and amino acid supplementation of European quails (Coturnix coturnix coturnix). Revista Brasileira de Zootecnia, 35 (2006), 822-829

DASZKIEWICZ, T.; PUDYSZAK, K.; MEHLER, Z.; MIKULSKI, D.:

Effect of feeding with mixtures of varied nutritional value on chemical composition and physicochemical and sensory properties of quail meat. Zeszyty Naukowe PTZ, (in Polish), 36 (1998), 313-315

GARDZIELEWSKA, J.; JAKUBOWSKA, M.; TARASEWICZ, Z.; SZCZERBIŃSKA, D.; LIGOCKI, M.: Meat quality of broiler quail fed on feeds with different protein content. Electronic Journal of Polish Agricultural Universities. Animal Husbandry 8, (2005)

GEBHARDT-HENRICH, S.G.; MARKS, H.L.:

Effects of feed restriction on growth and reproduction in random bred and selected lines of Japanese quail. Poult. Sci., 74 (1995), 402-406

GRAU, R.; HAMM, R.:

Über das Wasserbindevermögen das toten Säugetiermuskels. I. Mitteilung. Der Einfluss das pH-Wertes auf die Wasserbindung von zerkleinertem Rindermuskel. Biochem. 1 (1953), 325-328.

HOWES, J.R.; BEANE, W.L.:

The nutrition of Pheasants, Bob white and Coturnix quail. Feedstuffs, 38 (1966), 18-22

JAMROZ, D.; SCHLEICHER, A.; FRITZ, Z.:

Lowering of total protein level by about $30 \%$ in complete feed mixes for broilers when applying supplements of synthetic amino acids. (in Polish). Roczniki Naukowe Zootechniki, 8 (1981), 209-219

JAMROZ, D.; SCHLEICHER, A.; FRITZ, Z.; JAROSZ, L.:

Lowering of total protein level in concentrate feed mixes for 8974 inter-line hybrid chickens. (in Polish). Zeszyty Naukowe Akademii Rolnicze we Wrocławiu 142, Zootechnika 26 (1984), 63-75

KRAUSE, S.; BOŻYK, Z.; PIEKARSKI Z.:

Laboratory textbook of food analytical chemist, (in Polish). Warszawa, PZWL, (1966), 441-442

KUL, S.; SEKER, L; YILDRIM. O.:

Effect of separate and mixed rearing according to sex on fattening performance and carcass characteristics in Japanese ąuaiłs. Arch. Tierz., Dummerstorf 49 (2006), 607-641

ŁAMBUCKI, P.: Protein and amino acids in broiler chicken feeding, (in Polish). Hodowla Drobiu, 1 (2001), 19-21

MARKS, H.L.; SIEGEL, H.S.; LATIMER, J.W.:

Plasma cholesterol responses to adrenocorticotropic hormone in Japanese quail following eighteen generations of divergent selection. Poultry Science, 69 (1990), 205-208

MUSCALU G., PANAIT H., STEFANESCU V.:

Ways to improve broiler carcass quality by feeds with different energy and crude protein percentages.

Proc. XI Europ. Symp. Quality Poultry Meat, France - Tours, (1993), 153-156.

NUTRIENT REQUIREMENTS OF POULTRY:

Nutritive Value of Feeds. Ilnd ed. The Kielanowski Institute of Animal Phisiology and Nutrition (Editor), Jabłonna (in Polish), (1996), 88

OCAK, N.; ERENER, G.:

The effects of restricted feeding and feed form on growth, carcass characteristics and days to first egg of Japanese quail (Coturnix coturnix japonica). Asian-Australian Journal of Annimal Sciences, 18 (2005), 1479-1484

PUDYSZAK, K.; MIKULSKI, D.:

Effect of differentiated feeding on the utility traits of Japanese quails, (in Polish). Zeszyty Naukowe Przeglądu Hodowlanego, 36 (1998), 279-286

ROSEBROUGHT R.W., STEELE N.C.:

Energy and protein relations in the broiler. 1. Effect of protein levels and feeding regimes on growth, body composition and in vitro lipogenesis of broiler chicks. Poultry Sci., 64 (1985) 119-124

RUTKOWSKI, A.: Japanese quail. Poznań, PWRiL, (in Polish) (2000), 11-12

SHAHIN, K.A.; EL AZEEM, F.A.:

Effect of breed, sex and diet and their interactions on carcass composition and tissue weight distribution of broiler chickens. Arch. Tierz., Dummerstorf 48 (2005), 612-626

SHAHIN, K.A.; EL AZEEM. F.A.:

Effect of breed, sex and diet and their interactions on fat deposition and partitioning among depots of broiler chickens. Arch. Tierz., Dummerstorf 49 (2006), 181-193

STATISTICA software:

Copyright StatSoft Polska, 1995-2006., SEWSS, SEDAS, Data Miner, SEPATH and GTrees are trademarks of StatSoft 
SZCZUREK, W.; PISULEWSKI, P.:

Production indices and foeces nitrogen excretion in broiler chickens fed with low-protein feed mixes supplemented with pure amino acids, (in Polish). Zeszyty Naukowe Zootechniki Akademii Rolniczej w Krakowie, 23 (1996), 189-197

ŚWIERCZEWSKA, E.; NIEMIEC, J.; MROCZEK, J.; SIENICKA, A.; GRZYBOWSKA, A.; GROCHALSKA, A.:

The effect of feeding chickens with feed mixes with different protein content on production results, carcass tissue content and meat chemical composition, (in Polish). Zeszyty Naukowe Przeglądu Hodowlanego, 49 (2000), 365-375

TARASEWICZ, Z.:

Biological assessment of oligosaccharids isolated from Emir variety lupin (Lupinus angustifolius) seeds in feeding of a reproductive quail stock. Rozprawy 186, (Akademia Rolnicza w Szczecinie), (1998)

TARASEWICZ, Z.; LIGOCKI, M.; SZCZERBIŃSKA, D.; MAJEWSKA, D.; DAŃCZAK, A.:

Different level of crude protein and energy-protein ratio in adult quail diets. Arch. Tierz., Dummerstorf 49 (2006) Special Issue, 325-331

VOHRA, P.; ROUDYBUSK, T.:

The effect of Various Levels of Dietary Protein on the Growth and Egg Production of Coturnix coturnix japonica. Poultry Science, 50 (1971), 1081-1084

WERTELECKI, T.; JAMROZ, D.:

Yolk sac resorption rate, the development of digestive tract and alpha-amylase activity changes in serum of chicks and young chickens at the age from the 1st to 21 st day depending on the system of maintenance. Zeszyty Naukowe Przeglądu Hodowlanego, 32 (1997), 17-25

WILKIEWICZ-WAWRO, E.; BOCHNO, R.; WAWRO, K.; MICHALIK D.:

The effect of stocking and short-term limited feeding on the slaughter value of broiler chickens, (in Polish). Polish Journal of Natural Sciences, 14 (2003), 439-447

Received: 2007-02-09

Accepted: 2007-03-22

Authors' addresses

Dr habil. ZOFIA TARASEWICZ, Dr ing. MAREK LIGOCKI,

Dr habil. DANUTA SZCZERBIŃSKA, Dr ing. DANUTA MAJEWSKA

Agricultural University of Szczecin Department of Poultry Breeding

Ul. Dr Judyma 20

71-466 SZCZECIN / POLAND

Prof. dr habil. JADWIGA GARDZIELEWSKA, Dr ing. MAŁGORZATA JAKUBOWSKA Agricultural University of Szczecin Department of Livestock Products Evaluation

Ul. Dr Judyma 20

71-466 SZCZECIN / POLAND 